\title{
Alpha-Aminoisobutyric Acid Transport in Human Leukemic Lymphocytes: In Vitro Characteristics and Inhibition by Cortisol and Cycloheximide
}

\author{
Daniel T. Baran, Marshall A. Lichtman, and William A. Peck \\ From the Endocrine and Hematology Units, Department of Medicine, \\ University of Rochester School of Medicine and Dentistry, \\ Rochester, New York 14642
}

A в S T R A C T We have studied the transport of alphaaminoisobutyric acid (AIB) $-3-{ }^{14} \mathrm{C}$ and its response to cortisol and cycloheximide in vitro in blood lymphocytes from untreated patients with chronic lymphocytic leukemia. The accumulation of AIB-3- ${ }^{14} \mathrm{C}$ increased in a linear fashion for $60 \mathrm{~min}$, and reached an apparent steady state in 120 min. The initial rate of AIB accumulation ( $\mathrm{V}_{0}$ ) varied from 1.1 to $10.2 \mu$ moles $/ \mathrm{kg}$ cell $\mathrm{H}_{2} \mathrm{O}$ per min in cells from 16 different patients; however, $V_{0}$ was reproducible in cells from five of six patients which were studied repeatedly over 1-9 months, and correlated positively with the lymphocyte count $(r=0.51, P=<$ 0.01 ).

Virtually total inhibition of protein synthesis with cycloheximide was found to decrease the accumulation of AIB in cells from four patients which had high rates of AIB transport, but had no effect on transport in cells from four patients which accumulated AIB more slowly. These results indicate that active transport depends, in part, upon the presence of labile protein with a turnover rate which varies among different cell populations.

Treatment with $10 \mu \mathrm{M}$ cortisol for $240 \mathrm{~min}$ in vitro reduced the initial rate of AIB-3- ${ }^{14} \mathrm{C}$ accumulation ( $\mathrm{V}_{0}$ ) by $43.4 \pm 4.1 \%$ ( $\mathrm{SE}$ ) (range, 9-66\%) in cells from 16 patients. The degree of inhibition did not vary appreciably over a 9 month period in four of five patients. The effect of cortisol was proportional to its starting concentration, and developed at low concentrations $(0.1-1.0 \mu \mathrm{M})$. Cortisol appears to decrease AIB accumulation by in-

Published in part as an abstract in 1971. J. Clin. Invest. 52: 6a (Abstr.)

Dr. Lichtman is a Scholar of the Leukemia Society of America. Dr. Peck is recipient of U. S. Public Health Service Research Career Program Award AM 49931-01.

Received for publication 13 September 1971 and in revised form 18 January 1972. hibiting active uptake, since it neither enhanced the exodus of AIB, nor inhibited apparently nonsaturable transport. Inhibition was noncompetitive in type, suggesting that cortisol decreases the total capacity of the active transport mechanism.

Cortisol inhibited AIB transport indirectly by a process which involved de novo protein synthesis, since inhibition (a) appeared only after $60 \mathrm{~min}$ of treatment, (b) was present in treated cells which were subsequently incubated for $60 \mathrm{~min}$ in cortisol-free medium, and $(c)$ failed to develop during simultaneous blockade of protein synthesis with cycloheximide, even when cycloheximide itself did not decrease AIB transport.

\section{INTRODUCTION}

Although the manifestations of chronic lymphocytic leukemia vary greatly from patient to patient, cellular factors which contribute to this variation are poorly understood. A mounting body of evidence indicates that variations in the behavior of many types of mammalian cells are accompanied by significant alterations in plasma membrane function. Transport of certain free amino acids increases during periods of cell proliferation and heightened cell activity, and diminishes progressively with aging and with decreases in rates of growth (1-9). These observations suggest that an investigation of plasma membrane function might yield important information about the biological behavior of leukemic lymphocytes. In addition, the toxic effect of adrenal glucocorticoids on leukemic lymphocytes (10) which appears to underlie their therapeutic effectiveness in leukemic patients, may stem in part from modifications in plasma membrane function. Glucocorticoids have been found to impair the transport of a variety of substances, including free 
amino acids, in lymphoid cells obtained from experimental animals (11-22).

In the present study, we examine the characteristics of amino acid transport in human leukemic lymphocytes, and its variation in cell populations from different patients, and from the same patient at different times, using the nonmetabolizable amino acid alpha-aminoisobutyric acid (AIB). ${ }^{1}$ We also examine the effect of cortisol on AIB transport in order to determine the degree to which cortisol inhibits transport processes in human leukemic lymphocytes, and to explore the mechanism of this inhibition.

\section{METHODS}

Lymphocyte isolation. Venous blood was obtained from untreated subjects with chronic lymphocytic leukemia and the blood was anticoagulated with sodium heparin (14 U/ $\mathrm{ml}$ ). White cell and differential counts were performed and the leukocytes isolated after sedimentation of the red cells. 4 vol. of blood was added to 1 vol of $4.0 \%$ polyvinylpyrrolidone (PVP) in Hanks's balanced salt solution (HBSS) and incubated at room temperature for $90 \mathrm{~min}$. The supernate was removed and centrifuged for $5 \mathrm{~min}$ at $950 \mathrm{~g}$ in a Sorvall RC-3 General Purpose Centrifuge (Ivan Sorvall, Inc., Norwalk, Conn.) at $2^{\circ} \mathrm{C}$. The cells were suspended in HBSS, centrifuged at $950 \mathrm{~g}$ and resuspended in HBSS at a final concentration of $1.0-1.2 \times 10^{8}$ lymphocytes $/ \mathrm{ml}$. Red cell contamination was less than $8 \%$ as determined by counting 300 cells with a phase contrast microscope. Over $95 \%$ of leukocytes were lymphocytes.

Incubation conditions for AIB uptake. Lymphocyte suspensions were added in $0.4 \mathrm{ml}$ portions to flasks containing $2 \mathrm{ml}$ of HBSS with $0.05 \%$ albumin (four times recrystallized), or $2 \mathrm{ml}$ of $20 \%(\mathrm{v} / \mathrm{v})$ autologous or isologous plasma in HBSS, yielding a final concentration of 1.7-2.0 $\times$ $10^{7}$ lymphocytes $/ \mathrm{ml}$. Isologous plasma was obtained from healthy donors of red cell type AB. Cell suspensions were incubated at $37^{\circ} \mathrm{C}$ in a Dubnoff incubator and shaken at $10 \mathrm{cycle} / \mathrm{min}$ in air. Cortisol was added as a solution in absolute ethanol so that the final ethanol concentration was $0.04 \%(v / v)$. Untreated cell suspensions received an identical amount of ethanol. AIB, cortisol, and cycloheximide were added at times and in concentrations warranted by each experiment. At termination, the contents of each flask were transferred to cooled 2-ml conical centrifuge tubes (Kimax, Owens-Illinois, Inc., Toledo, Ohio) and sedimented at $950 \mathrm{~g}$ for $45 \mathrm{sec}$ at $2^{\circ} \mathrm{C}$. The supernate was decanted immediately, the side of each tube was dried, and the surface of the pellet was blotted with a thin strip of filter paper. The cell pellet was digested by incubation overnight in a National incubator (National Appliance Co., Portland, Oreg.) at $37^{\circ} \mathrm{C}$ in $0.5 \mathrm{ml}$ of $0.3 \mathrm{~m}$ potassium hydroxide $(\mathrm{KOH})$. $\frac{1}{10} \mathrm{ml}$ of $\mathrm{KOH}$ digest was added to $10 \mathrm{ml}$ of Bray's solution (23) and its total radioactivity determined in a Packard liquid scintillation spectrometer (Packard Instrument Co., Inc., Downer's Grove, III.). The degree of quenching was estimated by external standardization and

${ }^{1}$ Abbreviations used in this paper: AIB, alpha-aminoisobutyric acid; ECW, extracellular trapped water; FTR, fractional turnover rate; HBSS, Hanks's balanced salt solution; ICW, intracellular water; PVP, polyvinylpyrrolidone; $V_{0}$, initial rate of AIB accumulation. disintegrations per minute (dpm) calculated. The protein content of the cell pellet $\mathrm{KOH}$ digest was measured by the method of Lowry, Rosebrough, Farr, and Randall (24).

Persistence of the cortisol effect. To examine the persistence of the cortisol effect, lymphocytes were incubated for $3 \mathrm{hr}$ in the presence or absence of steroid. The cells were centrifuged at $950 \mathrm{~g}$ at $25^{\circ} \mathrm{C}$ in $2-\mathrm{ml}$ conical tubes (Kimax, Owens-Illinois, Inc., Toledo, Ohio), and resuspended in steroid-free medium, and incubated at $37^{\circ} \mathrm{C}$ for $60 \mathrm{~min}$ at which time AIB uptake was measured.

Incorporation of leucine-1-1" $C$ into protein. The inhibitory effect of cycloheximide on protein synthesis was verified by measuring the incorporation of leucine- $1{ }^{14} \mathrm{C}$ into protein. Lymphocytes were incubated in the presence and absence of cycloheximide, $100 \mu \mathrm{g} / \mathrm{ml}$, for $240 \mathrm{~min}$. Leucine$1-{ }^{14} \mathrm{C}$ was added for the last $2 \mathrm{hr}$ of incubation. Protein was precipitated with $2 \mathrm{ml}$ of $10 \%$ trichloroacetic acid (TCA) at $0^{\circ} \mathrm{C}$. The resulting precipitate was centrifuged at $950 \mathrm{~g}$ for $5 \mathrm{~min}$, and washed once with $2 \mathrm{ml}$ of $10 \%$ TCA and once with $2 \mathrm{ml}$ of diethyl ether. The TCAether insoluble fraction was dissolved overnight at $37^{\circ} \mathrm{C}$ in $0.5 \mathrm{ml}$ of $0.3 \mathrm{M} \mathrm{KOH}$. $\frac{1}{10} \mathrm{ml}$ of the digest and $0.1 \mathrm{ml}$ of the TCA soluble fraction were added to $10 \mathrm{ml}$ of Bray's solution (23) and their radioactivities determined.

Estimation of intracellular water $(I C W)$. Replicate treated and untreated cell suspensions were incubated with sucrose $-{ }^{14} \mathrm{C}$ in place of AIB-3- ${ }^{14} \mathrm{C}$ and centrifuged in tared $2-\mathrm{ml}$ conical tubes. The wet weight of the pellet was determined and the cell pellet dried at $80^{\circ} \mathrm{C}$ for $18 \mathrm{hr}$. Total pellet water was calculated by subtracting the dry pellet weight from its wet weight. The dry pellet was digested in $0.5 \mathrm{ml}$ of $0.3 \mathrm{M} \mathrm{KOH}$ and the radioactivity of $0.1 \mathrm{ml}$ of the digest measured in $10 \mathrm{ml}$ of Bray's solution (23). Extracellular trapped water (ECW) was calculated by dividing total pellet radioactivity by the radioactivity per $0.1 \mathrm{ml}$ of the incubation medium. ICW (total pellet water minus ECW) was $65-75 \%$ of the total cell weight. Neither cortisol nor cycloheximide altered the ECW or ICW after 1-4 hr of exposure.

Calculation of intracellular amino acid content and expression of transport data. The intracellular accumulation of labeled amino acid per milliliter of ICW $\left(\mathrm{AIB}_{1}\right)$ was calculated from the formula :

$$
A I B_{i}=\frac{R_{t}-\left(A I B_{0} \times V_{0}\right)}{V_{t}-V_{t}}
$$

where $R_{t}$ equals the net radioactivity of the cell pellet, $\mathrm{AIB}_{0}$ the radioactivity per milliliter of incubation medium, $V_{0}$ the volume of ECW in milliliters, and $V_{t}$ the total pellet water in milliliters. Results are expressed either as the distribution ratio $\mathrm{AIB}_{1} / \mathrm{AIB}_{0}\left(\mathrm{~A}_{1} / \mathrm{A}_{0}\right)$ where $\mathrm{AIB}_{1}$ is radioactivity per milliliter of cell water, and $\mathrm{AIB}_{0}$ the radioactivity per milliliter of incubation medium or as $\mathrm{V}_{0}$, $\mu$ moles $\cdot \mathrm{kg}^{-1}$ cell $\mathrm{H}_{2} \mathrm{O} \cdot \mathrm{min}^{-1}$ ( $\mu$ moles $/ \mathrm{kg}$ cell $\mathrm{H}_{2} \mathrm{O}$ per min) calculated from the formula: $\mathrm{V}_{0}=A \mathrm{IB}_{1} /$ specific activity AIB-3- ${ }^{14} \mathrm{C}$ per time of label in minutes. The contribution of apparently nonsaturable transport to the accumulation of AIB was estimated according to the method of Akedo and Christensen (25) and kinetic data were adjusted to represent saturable transport.

Materials. Cortisol of the highest purity was purchased from Calbiochem, Los Angeles, Calif. AIB-3- ${ }^{14} \mathrm{C}(1 \mathrm{mCi} /$ mmole), leucine-1-14 $\mathrm{C}$ (4 $\mathrm{mCi} / \mathrm{mmole})$, sucrose-UL- ${ }^{14} \mathrm{C}$ (5 $\mathrm{mCi} / \mathrm{mmole}$ ) were obtained from New England Nuclear 


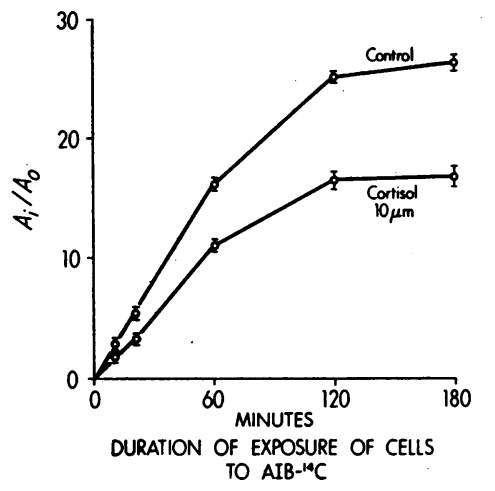

Figure 1 Time-course of AIB accumulation in cortisoltreated and untreated leukemic lymphocytes. Cells from patient W. F. were incubated for $240 \mathrm{~min}$ in the presence or absence of $10 \mu \mathrm{M}$ cortisol. AIB-3- ${ }^{14} \mathrm{C}$ was then added to each flask so that its concentration in the medium was 10 $\mu \mathrm{M}$, and the incubation was continued for an additional 10 $180 \mathrm{~min}$. The data represent distribution ratios of $\mathrm{AIB}-3-{ }^{14} \mathrm{C}$ $\left(A_{1} / A_{0}\right)$ at each time point. Longer periods of labeling (e.g. $180 \mathrm{~min}$ ) were necessarily associated with longer periods of exposure (e.g. $420 \mathrm{~min}$ ) to cortisol. These experimental conditions would not be expected to cause a greater degree of inhibition than that seen in cells which were treated for a shorter period of time, since cortisol inhibition appears to be maximal in $3-4 \mathrm{hr}$ (see Fig. 5).

Corp., Boston, Mass., and cycloheximide from Sigma Chemical Co., St. Louis, Mo.

Statistical methods. Means, variances, correlation coefficients, coefficients of variation, and regression lines were calculated by standard formulas.

\section{RESULTS}

Initial rates and equilibrium values of $A I B$ transport in untreated and cortisol-treated leukemic lymphocytes. The accumulation of AIB by leukemic lymphocytes increased in linear fashion for the first $60 \mathrm{~min}$ of exposure to AIB-3 $3{ }^{14} \mathrm{C}$ and reached an apparent steady state in $120 \mathrm{~min}$ (Fig. 1). In order to compare AIB transport in leukemic lymphocytes from different patients, we examined initial rates of AIB accumulation $\left(V_{0}\right)$, which were calculated from the amount of AIB$3-{ }^{14} \mathrm{C}$ accumulated during the first $20 \mathrm{~min}$ of exposure to AIB, after a preliminary incubation for $4 \mathrm{hr}$ without added AIB. These studies revealed marked variation in the magnitude of $V_{0}$ between cell populations from 16 patients (Table I), but little variation among quadruplicate samples from the same cell population (Table I legend). The source of plasma added to the incubation medium did not influence the rate of AIB accumulation. Vo was virtually constant in cells from the same patient incubated in medium containing isologous plasma from each of several different sources, or in autologous plasma (data not shown). There was a significant positive correlation $(r=0.51, P<0.01)$ between $\mathrm{V}_{0}$ and the lym-
TABLE I

Initial Rates of AIB Accumulation ( $\left.V_{0}\right)$ by Cortisol-Treated and Untreated Lymphocytes from Patients with Chronic Lymphocytic Leukemia

\begin{tabular}{|c|c|c|c|c|}
\hline \multirow[b]{2}{*}{ Subject } & \multirow{2}{*}{$\begin{array}{l}\text { White cell } \\
\text { count }\end{array}$} & \multicolumn{2}{|c|}{$V_{0}$} & \multirow{2}{*}{$\begin{array}{c}\text { Cortisol } \\
\text { inhibition }\end{array}$} \\
\hline & & Control & Cortisol & \\
\hline & $\times 10^{2} / \mu l$ & umoles $/ \mathrm{kg}$ cell & $\mathrm{H}_{2} \mathrm{O}$ per min & $\%$ \\
\hline F. Ho. & 240 & 10.2 & 4.9 & 52 \\
\hline L. K. & 900 & 6.4 & 5.1 & 20 \\
\hline A. M. & 35 & 6.1 & 3.0 & 51 \\
\hline B. R. & 365 & 6.1 & 3.7 & 39 \\
\hline F. Ha. & 131 & 4.9 & 1.7 & 65 \\
\hline V.S. & 240 & 4.8 & 3.1 & 35 \\
\hline L. S. & 208 & 4.4 & 3.0 & 32 \\
\hline A. B. & 98 & 4.1 & 1.4 & 66 \\
\hline M. M. & 172 & 3.7 & 1.8 & 51 \\
\hline G. B. & 160 & 3.3 & 1.4 & 58 \\
\hline W. F. & 87 & 2.7 & 1.7 & 37 \\
\hline G. L. & 46 & 2.3 & 1.4 & 39 \\
\hline F. A. & 31 & 2.3 & 1.2 & 48 \\
\hline K. C. & 21 & 1.6 & 1.1 & 31 \\
\hline E. F. & 90 & 1.3 & 0.5 & 62 \\
\hline H. S. & 36 & 1.1 & 1.0 & 09 \\
\hline Mean $\pm \mathrm{SE}$ & & $4.1 \pm 0.6$ & $2.3 \pm 0.3$ & $43.4 \pm 4.1$ \\
\hline
\end{tabular}

Lymphocytes from each patient were incubated at $37^{\circ} \mathrm{C}$ for a total of $260 \mathrm{~min}$ in the presence or absence of $10 \mu \mathrm{M}$ cortisol. AIB-3-14 C was added to each cell suspension $20 \mathrm{~min}$ before termination in a concentration of $10 \mu \mathrm{M}$. Each value for $V_{0}$ represents the mean of four separate cell suspensions which were incubated and prepared simultaneously. The average coefficient of variation for these quadruplicate observations was $11.4 \%$.

phocyte count (Fig. 2) indicating that about 25\% $\left(r^{2}=0.25\right)$ of the variation in AIB accumulation or in lymphocyte count is due to variation in the other.

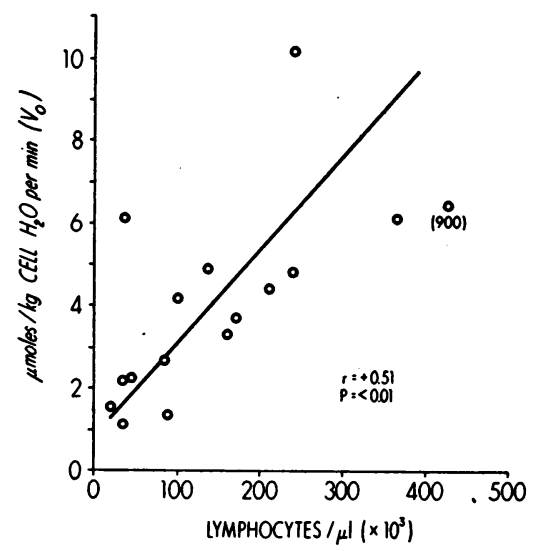

Figure 2 Correlation of $V_{0}$ with blood lymphocyte count in 16 patients with chronic lymphocytic leukemia. Individual values are also given in Table $\mathrm{I}$. 


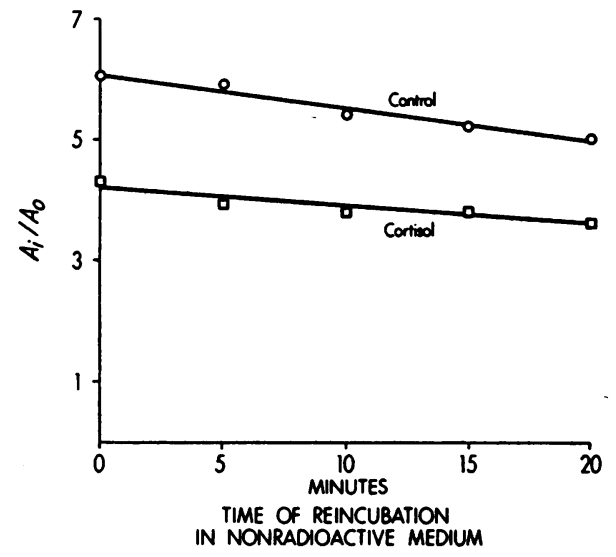

FIgURE 3 Effect of cortisol on the exodus of AIB-3- ${ }^{14} \mathrm{C}$. Cells from patient A. B. were distributed into 50-ml Erlenmeyer flasks containing $25 \mathrm{ml}$ of incubation medium, with or without cortisol, $10 \mu \mathrm{M}$. After incubation for $180 \mathrm{~min}$, AIB- $3-{ }^{14} \mathrm{C}$ was added to each cell suspension so that its concentration in the medium was $3.3 \mu \mathrm{M}$, and the incubation continued for an additional $120 \mathrm{~min}$. The reduced concentration of AIB was used so as to obtain steady-state cellular AIB concentrations which approximated those seen after $20 \mathrm{~min}$ of exposure to $\mathrm{AIB}-3-{ }^{14} \mathrm{C}$. Cells from each flask were harvested by centrifugation, and resuspended in AIBfree medium at $37^{\circ} \mathrm{C}$ with or without cortisol according to their treatment during the initial period of incubation. The resuspended cells were transferred to new $50-\mathrm{ml}$ flasks, and incubated for $20 \mathrm{~min}$. 2 - $\mathrm{ml}$ portions of each cell suspension were removed at the start of the incubation, and every 5 min thereafter, and the cellular concentration of AIB-3-14 C was estimated as described under Methods. The data are given as distribution ratios of $\mathrm{AIB}-3-{ }^{14} \mathrm{C}\left(\mathrm{A}_{1} / \mathrm{A}_{0}\right)$ at each point in time.

Treatment with $10 \mu_{\mathrm{M}}$ cortisol for $4 \mathrm{hr}$ reduced the initial rate of AIB accumulation ( $V_{0}$ ) in cells from 16 patients by a mean of $43.4 \pm 4.1 \%$ (SE). A statistically significant $(P<0.05)$ reduction appeared in cells from 15 of 16 patients (Table I). Cortisol was found to inhibit $\mathrm{V}_{0}$ and the apparent steady-state accumulation of AIB to the same degree (Fig. 1).

The fact that cortisol decreased the initial rate of accumulation suggests that it inhibited the uptake of AIB, since exodus would not be expected to modify net AIB accumulation appreciably during this period. This interpretation was substantiated by the failure of cortisol to enhance the exodus of AIB from cells which had been exposed to AIB-3 ${ }^{14} \mathrm{C}$ for $180 \mathrm{~min}$ before transfer to a medium free of AIB (Fig. 3). The fractional turnover rate (FTR) of AIB-3 $-{ }^{14} \mathrm{C}$ was calculated by the formula $\left(\ln (A I B) t_{1}-\ln (\text { AIB })_{t_{2}}\right) /\left(t_{2}-t_{1}\right)$, where $t_{1}=$ zero time and $t_{2}=20 \mathrm{~min}$. The FTR of AIB from cortisol-treated cells was less $(0.0069)$ than that of control cells $(0.0099)$; however, this difference was accounted for by the higher gradient for exodus in control cells. Initial pool size (concentration) of AIB was $48 \%$ greater and FTR $43 \%$ greater in control as compared with cortisol-treated cells. These data indicate that the inhibition of AIB accumulation by cortisol at apparent steady state is not explained by an acceleration of exodus.

Reproducibility of AIB accumulation and of sensitivity to cortisol. Since the magnitude of $\mathrm{V}_{0}$ and cortisol inhibition varied over a wide range in different populations of leukemic cells, we studied cells from the same patients at different times over a 9 month period to determine the reproducibility of amino acid accumulation and cortisol sensitivity. Little variation in $V_{0}$ was seen on the numerous occasions when an individual patient was studied on successive days or weeks, suggesting that the differences in $V_{0}$ between patients did not stem from experimental variation. There was a small to moderate degree of variation in $V_{0}$ in cells from five of six patients (W. F., G. B., M. M., V. S., and L. K.) restudied at longer intervals (Table II), and marked variation in one patient (A. B.). The degree of cortisol inhibition did not vary appreciably in cells from five patients studied at different times (G. B., V. S., M. M., A. B., and L. K.) and varied greatly in one patient (W. F.).

Effects of cortisol on the kinetic parameters of active AIB transport and on transport which is apparently non-

TABLE II

Reproducibility of AIB Accumulation and Cortisol (10 $\mu \mathrm{M})$ Sensitivity in Six Patients

\begin{tabular}{lrccc}
\hline Patient & Date & Control & Cortisol & $\begin{array}{c}\text { Cortisol } \\
\text { inhibition }\end{array}$ \\
\hline & & $\mu$ moles $/$ kg cell & $H_{2} O$ per $\min$ & $\%$ \\
W. F. & $9-70$ & $2.7 \pm 0.1$ & $1.7 \pm 0.1$ & 37 \\
& $1-71$ & $2.9 \pm 0.1$ & $1.3 \pm 0.1$ & 55 \\
& $3-71$ & $3.1 \pm 0.2$ & $2.4 \pm 0.1$ & 23 \\
& $5-71$ & $2.5 \pm 0.1$ & $1.7 \pm 0.1$ & 32 \\
& $6-71$ & $2.9 \pm 0.2$ & - & - \\
G. B. & $11-70$ & $3.3 \pm 0.3$ & $1.4 \pm 0.1$ & 58 \\
& $2-71$ & $3.2 \pm 0.4$ & $1.5 \pm 0.05$ & 53 \\
& $6-71$ & $4.3 \pm 0.4$ & $1.7 \pm 0.3$ & 60 \\
M. M. & $11-70$ & $3.7 \pm 0.4$ & $1.8 \pm 0.2$ & 51 \\
& $12-70$ & $3.2 \pm 0.3$ & $1.9 \pm 0.4$ & 41 \\
& $5-71$ & $2.9 \pm 0.1$ & $1.5 \pm 0.1$ & 48 \\
V. S. & $1-71$ & $4.8 \pm 0.2$ & $3.1 \pm 0.2$ & 35 \\
& $1-71$ & $4.9 \pm 0.3$ & $3.3 \pm 0.06$ & 33 \\
& $6-71$ & $3.7 \pm 0.2$ & - & - \\
A. B. & $11-70$ & $4.1 \pm 0.8$ & $1.4 \pm 0.1$ & 66 \\
& $6-71$ & $1.5 \pm 0.1$ & $0.6 \pm 0.04$ & 60 \\
L. K. & $10-70$ & $6.4 \pm 0.3$ & $5.1 \pm 0.2$ & 20 \\
& $11-71$ & $6.9 \pm 0.2$ & $6.1 \pm 0.2$ & 12 \\
\hline
\end{tabular}

Lymphocytes were treated as described in Table I. Each value represents the mean $\pm \mathrm{SE}$ of quadruplicate determinations of $V_{0}$ (micromoles/kilogram cell $\mathrm{H}_{2} \mathrm{O}$ per minute). 
saturable. To determine more precisely the nature of cortisol action on AIB uptake, we studied the kinetic parameters of active transport by leukemic lymphocytes. Graphic representation of $V_{0}$ according to the method of Lineweaver and Burke, at AIB concentrations ranging from 10 to $500 \mu_{\mathrm{M}}$, indicated the presence of a single transport process having an apparent $K_{m}$ of $0.48 \mathrm{~mm}$ and a $V_{\max }$ of $200 \mu$ moles $/ \mathrm{kg}$ cell $\mathrm{H}_{2} \mathrm{O}$ per min (Fig. 4). Treatment with $10 \mu_{\mathrm{M}}$ cortisol for $4 \mathrm{hr}$ markedly decreased the $V_{\max }$ but failed to alter the apparent $K_{m}$ appreciably, suggesting, under conventional assumptions, a decrease in the total capacity of the transport mechanism for AIB rather than a decreased affinity of AIB for the cells. We performed additional experiments 2 wk later with cells from the same patient, using a higher concentration range of AIB ( $500 \mu_{\mathrm{M}}$ to $5 \mathrm{mM}$ ), and represented the results in an alternate graphic form, $V_{\text {o }}$ vs. $V_{\circ} / C_{a}$, which has been found by Dowd and Riggs to give statistically more reliable estimates for apparent $K_{m}$ and $V_{\max }$ (26) (not shown). These experiments yielded kinetic parameters $\left(V_{\max }=\right.$ control, $183 \mu$ moles $/ \mathrm{kg}$ cell $\mathrm{H}_{2} \mathrm{O}$ per min; cortisol $82 \mu$ moles $/ \mathrm{kg}$ cell $\mathrm{H}_{2} \mathrm{O}$ per min; $K_{m}=$ control, $0.62 \mu_{\mathrm{M}}$; cortisol, $0.51 \mu_{\mathrm{M}}$ ) which were similar to those obtained with the Lineweaver and Burke representation, and therefore support the interpretation that cortisol inhibits the total capacity for AIB transport. The similarity of the kinetic parameters observed at $10-500 \mu_{\mathrm{M}}$ AIB and at $500 \mu_{\mathrm{M}}$ to $5 \mathrm{~mm}$ AIB is consistent with the presence of a single active mechanism for AIB transport.

To determine whether cortisol inhibits nonsaturable as well as saturable uptake of AIB, cortisol-treated and untreated lymphocytes were labeled with a concentration of AIB (20 mM) at which apparent nonsaturable uptake accounts for $80 \%$ of AIB accumulation over the $20 \mathrm{~min}$ of study (see Fig. 4 for $V_{\max }$ ). Cortisol had no effect on the accumulation of AIB under these conditions (Table III) suggesting that its action is limited to the saturable mechanism for AIB transport.

Time-course, dose-response relationships, and persistence of cortisol effect. Glucocorticoids are known to inhibit the uptake of free amino acids in rat thymic lymphocytes in vitro (19-22). This inhibition appears to arise indirectly, since it develops at low steroid concentrations, is delayed in onset, depends on continued protein synthesis, and persists after treated cells are transferred to steroid-free medium (19-22). To determine whether cortisol inhibits AIB uptake in human leukemic lymphocytes by a similar indirect mechanism, we examined the time of onset and disappearance of cortisol inhibition and its dose-response relationships. No statistically significant effect was produced by $1 \mathrm{hr}$ of treatment in any of the four patients studied (Fig. 5). Statistically significant inhibition was evident at $2 \mathrm{hr}$ in the one patient studied

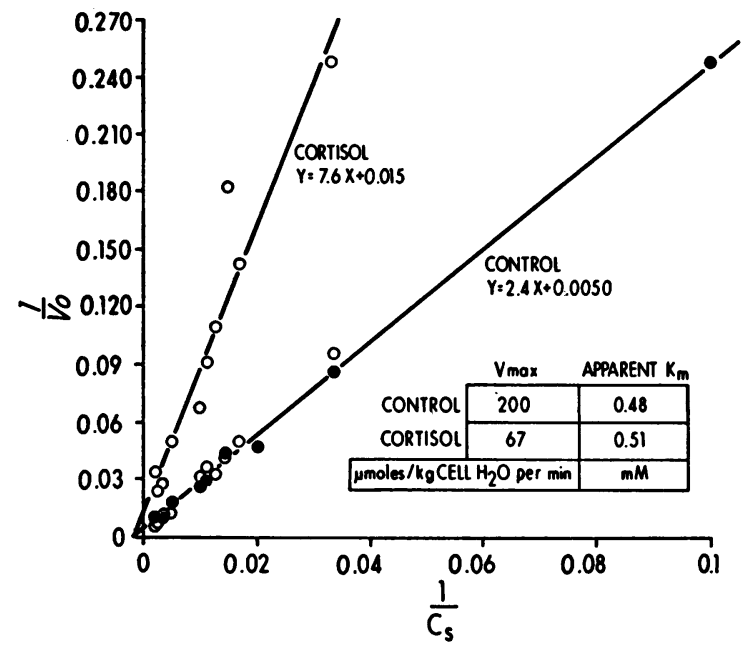

FIgURE 4 Lineweaver-Burk representations of initial rates of AIB-3- ${ }^{14} \mathrm{C}$ accumulation (in this case expressed as micromoles/kilogram cell $\mathrm{H}_{2} \mathrm{O}$ per minute) at concentrations of AIB $\left(\mathrm{C}_{\mathrm{s}}\right)$ ranging from 10 to $500 \mu \mathrm{M}$. Lymphocytes from patient M. M. were incubated for $260 \mathrm{~min}$ in the presence or absence of cortisol, $10 \mu \mathrm{M}$, and were exposed to AIB-3${ }^{14} \mathrm{C}$ during the final $20 \mathrm{~min}$ of this period. Various AIB concentrations were achieved by adding an appropriate amount of nonradioactive AIB and a constant amount of AIB-3- $-{ }^{14} \mathrm{C}$ to the cell suspensions. The experimentally observed points were found to satisfy the assumption of linearity required for linear regression analysis which was used to obtain equations defining the two lines. The data for untreated cells are the composite of two separate experiments performed at a 30 day interval. These experiments produced virtually identical kinetic parameters for AIB-3-14 C accumulation.

at that time and at $3 \mathrm{hr}$ in all patients. In order to determine whether established cortisol inhibition persisted in the absence of steroid, we examined AIB uptake in lymphocytes which had been treated for $180 \mathrm{~min}$ and then transferred to steroid-free medium. Marked inhibition of AIB accumulation persisted for $60 \mathrm{~min}$ after

TABLE III

Effect of Cortisol $(10 \mu \mathrm{M})$ on the Accumulation of $A I B$ at High and at Low AIB Concentrations

\begin{tabular}{ccccc}
\hline \multicolumn{2}{c}{$10 \mu \mathrm{M}$ AIB } & \multicolumn{2}{c}{$20 \mathrm{mM}$ AIB } \\
\cline { 2 - 3 } Control & Cortisol & & Control & Cortisol \\
\hline \multirow{4}{*}{$4.3 \pm 0.3$} & $1.7 \pm 0.2$ & $1100 \pm 25$ & $1050 \pm 26$ \\
\hline
\end{tabular}

Lymphocytes from patient $\mathrm{G}$. B. were treated and incubated with AIB-3- ${ }^{14} \mathrm{C}$ as described in Table I. AIB-3-14 $\mathrm{C}$ was diluted with nonradioactive AIB before addition in order to achieve a concentration of $20 \mathrm{~mm}$. Each value represents the mean $\pm \mathrm{SE}$ of quadruplicate determinations of $\mathrm{V}_{0}$ (micromoles/ kilogram cell $\mathrm{H}_{2} \mathrm{O}$ per minute). 


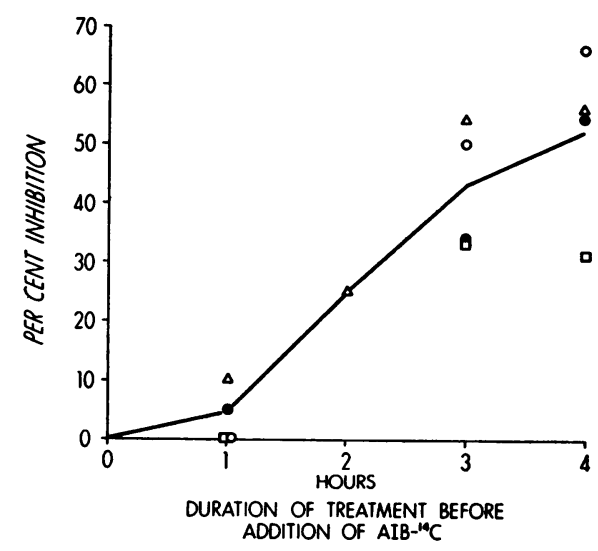

FIgURE 5 Time-course of cortisol inhibition of AIB transport. Lymphocytes were obtained from four patients $(O$, A. B.; $\triangle$, W. F.; $\bullet$, G. B.; $\square$, V. S.) and incubated in the presence or absence of cortisol $(10 \mu \mathrm{M})$ for $1,2,3$, or $4 \mathrm{hr}$. The cell suspensions received AIB-3- ${ }^{14} \mathrm{C} 20 \mathrm{~min}$ before the termination of each treatment period. For convenience of presentation, data are presented as per cent inhibition. Periods of treatment longer than $4 \mathrm{hr}$ caused no greater inhibition. Absolute values for $V_{0}$ at $4 \mathrm{hr}$ of treatment appear in Table II.

transfer in lymphocytes from two patients (54 and $47 \%$, respectively). In studies with two separate patients, the degree of inhibition of AIB uptake was directly related to the starting concentration of cortisol (Fig. 6). Moreover, as little as $0.1 \mu_{\mathrm{M}}$ cortisol was inhibitory in cells from one patient (A. B.).

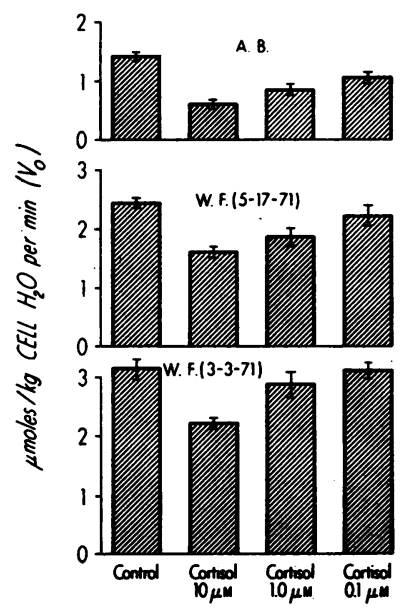

FIGURE 6 Degree of inhibition of AIB transport by cortisol in concentrations ranging from 0.1 to $10 \mu \mathrm{M}$. Lymphocytes were treated as indicated in the figure for $260 \mathrm{~min}$, including a final $20 \mathrm{~min}$ period of labeling with $10 \mu \mathrm{M}$ AIB$3-{ }^{14} \mathrm{C}$. All three concentrations of cortisol inhibited AIB accumulation to a statistically significant degree $(P<$ 0.01 ) in cells from patient A. B., whereas only $10 \mu \mathrm{M}$ cortisol produced a statistically significant effect $(P<0.01)$ in cells from patient W. F.
Effects of cycloheximide on AIB transport and its inhibition by cortisol. Cycloheximide, a potent inhibitor of protein synthesis in lymphoid cells (27), has been shown to decrease the uptake of AIB in rat thymic lymphocytes (22), suggesting that labile protein may be involved in the transport of low molecular weight substrates across the lymphocyte plasma membrane. Hence, cortisol could decrease AIB transport in leukemic lymphocytes by inhibiting the replenishment of such a labile transport protein. Alternatively, cortisol could act by a mechanism which requires de novo protein synthesis (e.g. by inducing the synthesis of a protein which inhibits transport). To differentiate between these possibilities, lymphocytes were incubated in the presence of cycloheximide, cortisol, or both. Treatment with cycloheximide for $4 \mathrm{hr}$ inhibited the transport of AIB to a statistically significant degree in cells from only four of eight patients (Table IV). Studies performed in parallel (data not shown) revealed that cycloheximide inhibited the incorporation of leucine- $1{ }^{14} \mathrm{C}$ into protein by more than 95\% whether or not it decreased AIB transport. The same results were obtained when one cycloheximidesensitive and one cycloheximide-resistant cell population were studied again (Table IV). It is of particular interest that the four cell populations which responded to cycloheximide with decreased AIB accumulation had higher rates of AIB transport than any of the nonresponsive populations. Moreover, cycloheximide inhibited AIB accumulation to the greatest degree in cells from

TABLE IV

Effect of Cortisol and Cycloheximide on the Accumulation of $A I B$

\begin{tabular}{|c|c|c|c|c|}
\hline Subject & Control & $\begin{array}{c}\text { Cortisol, } \\
10 \mu \mathrm{M}\end{array}$ & $\begin{array}{c}\text { Cycloheximide, } \\
360 \mu \mathrm{M}\end{array}$ & $\begin{array}{l}\text { Cortisol }+ \\
\text { cycloheximide }\end{array}$ \\
\hline \multicolumn{5}{|c|}{ Sensitive to cycloheximide } \\
\hline 1. F. Ho. & 10.2 & 4.9 & 4.4 & - \\
\hline 2. V.S. & 4.8 & 3.1 & 3.6 & 3.4 \\
\hline 3. F. Ha. & 4.9 & 1.7 & 3.2 & 3.6 \\
\hline 4. L.S. & 4.4 & 3.0 & 3.4 & 3.3 \\
\hline Mean \pm SE & $6.1 \pm 1.4$ & $3.2 \pm 0.7$ & $3.7 \pm 0.3$ & $3.4 \pm 0.1$ \\
\hline \multicolumn{5}{|c|}{ Resistant to cycloheximide } \\
\hline 5. G. B. & 3.3 & 1.4 & 3.6 & 3.6 \\
\hline 6. M. M. & 2.9 & 1.5 & 2.8 & 3.0 \\
\hline 7. F. A. & 2.3 & 1.2 & 2.0 & 1.9 \\
\hline 8. W. F. & 2.5 & 1.7 & 2.8 & 2.8 \\
\hline Mean \pm SE & $2.7 \pm 0.3$ & $1.5 \pm 0.1$ & $2.8 \pm 0.3$ & $2.8 \pm 0.4$ \\
\hline \multicolumn{5}{|c|}{ Reexamination ( $R$ ) } \\
\hline 2R V.S. & 3.7 & & 2.9 & \\
\hline 8R W. F. & 2.9 & & 3.2 & \\
\hline
\end{tabular}

Lymphocytes were treated as indicated for a total of $260 \mathrm{~min}$, and received AIB-3-14C $20 \mathrm{~min}$ before termination. Each value represents the mean of quadruplicate estimations of $\mathrm{V}_{0}$. Variances for quadruplicates are not shown. Differences between control and cortisol values (patients 1-8) are all statistically significant $(P<0.05)$. Differences between control and cycloheximide values are statistically significant $(P<0.05)$ only in cells from patients 1-4. 
patient F. Ho., which transported AIB more than twice as rapidly as cells from other patients. Cycloheximide prevented the appearance of cortisol inhibition in cells from all eight patients when they were treated with both agents simultaneously (Table IV). The fact that virtually complete blockade of protein synthesis failed to inhibit AIB uptake in some cases, yet prevented cortisol inhibition in all cases is most suggestive of a mechanism in which cortisol acts by promoting the synthesis of new protein.

\section{DISCUSSION}

The presence of intrinsic differences in the active mechanism for AIB transport best explains the observed variation in $V_{0}$ among different leukemic lymphocyte populations. Experimental variation, and differences in the extracellular concentrations of other free amino acids and in the rate of protein synthesis do not appear to account for these differences, since $V_{0}$ was quite reproducible in cells from the same patient at different times and incubated in plasma from different sources, and was not altered by cycloheximide in some cell populations. The fact that $V_{0}$ could be correlated with the blood lymphocyte count suggests that transport of free amino acids might determine the ability of lymphocytes to proliferate or survive. This possibility is supported by the previous demonstration that an acceleration of AIB transport precedes the proliferation of human lymphocytes induced by phytohemagglutinin in vitro (8).

The ability of cycloheximide to inhibit AIB transport in some lymphocyte populations provides indirect evidence for the participation of protein with a short halflife in the transport system, as has been proposed in other tissues (e.g. rat diaphragm, thymic lymphocytes, embryonic chick bone $[17,28-31])$. Although inhibition of protein synthesis could have decreased transport by disrupting cell function generally, or by increasing extracellular concentrations of competitive free amino acids, the failure of cycloheximide to modify the transport of AIB in half of the cell populations studied despite near total inhibition of protein synthesis argues against these possibilities.

The nature of this putative transport protein is unknown. However, the finding that the magnitude of $\mathrm{V}_{\mathrm{o}}$ was greater in cycloheximide-sensitive than in cycloheximide-resistant cells suggests that it may be of considerable functional significance. Differences in its rate of turnover could determine the overall rate of amino acid transport. Alternatively, the active transport of AIB might be mediated by two separate mechanisms, one of which depends upon such a protein, but is not present in all leukemic lymphocyte populations. Furthermore, the magnitude of $\mathrm{V}_{\mathrm{o}}$, which is related to the mass of circulating lymphocytes as well as cycloheximide sensi- tivity, might be a function of cell age. In studies with rat diaphragm in vitro, Elsas, MacDonell, and Rosenberg have shown that the rate of amino acid transport and the sensitivity of transport to inhibitors of protein synthesis are inversely related to the age of the study animals (9).

The experimental results indicate that cortisol inhibits active AIB transport indirectly, and by a process which requires de novo protein synthesis. Inhibition appeared slowly and at low concentrations, persisted after transfer of treated cells to cortisol-free medium, and was not seen during simultaneous inhibition of protein synthesis. The observation that virtually complete inhibition of protein synthesis with cycloheximide did not in itself decrease AIB transport in cells from four of eight patients, but nullified the effect of cortisol in each case, strongly favors the hypothesis that synthesis of new protein is involved in inhibition of amino acid transport. Kinetic studies in cells from one patient suggest that this protein may regulate the total capacity $\left(V_{\max }\right)$ of the transport system, rather than the affinity (apparent $K_{m}$ ) of the system for AIB. However, these kinetics must be confirmed in studies with additional patients because of the wide variation between patients in rates of AIB transport and cortisol sensitivity.

Cortisol has been found to exert many effects on the metabolism of animal lymphocytes, including inhibition of transport processes (11-22), and of macromolecule synthesis $(19,20,22,32,33)$ and these effects appear to arise indirectly. Studies of Mosher, Young, and Munck (34) and Munck (35) indicate that an initial binding of glucocorticoids to specific nuclear receptors may trigger the de novo synthesis of RNA and protein, and that this protein (or proteins) mediates in an unknown fashion the subsequent inhibitory effects of the hormone.

The inhibitory effect of cortisol on AIB transport in human leukemic lymphocytes may not be related entirely to its glucocorticoid activity, since nonglucocorticoids in high concentration (e.g. $10 \mu_{\mathrm{M}}$ progesterone) have been found to exert a similar effect in animal lymphocytes (19). This would imply that glucocorticoid-specific receptors are not involved in this action of cortisol. However, the response of human lymphocytes to cortisol resembled the glucocorticoid-specific responses of thymic lymphocytes in two ways: sensitivity to low concentrations of hormone $\left(0.1 \mu_{\mathbf{M}}\right.$ and $\left.1 \mu_{\mathbf{M}}\right)$, and a requirement for de novo protein synthesis. Additional studies with lower cortisol concentrations and with other steroids will be necessary in order to establish the specificity of cortisol action in the human cells.

The wide but reproducible variation in the degree to which cortisol inhibited AIB transport in leukemic lymphocytes from different patients was noteworthy. Each cell population may possess a characteristic sensi- 
tivity to cortisol, since, in most instances, the effectiveness of cortisol on a given cell population did not change with time. Many factors could participate in determining this sensitivity. One important possibility is that cortisol sensitivity may depend on the number or affinity of cellular receptors. Indeed, mouse lymphosarcoma cells which are resistant to the metabolic effects of glucocorticoids appear to bind less glucocorticoid than hormone-sensitive lymphosarcoma cells $(36,37)$.

Glucocorticoids produce a late $(3-4 \mathrm{hr})$ decrease in the incorporation of amino acids and nucleosides into protein and nucleic acids in human leukemic lymphocytes in vitro $(38,39)$. Since a shorter period of treatment suffices to inhibit the uptake of free amino acids, these changes in incorporation may result from impaired transport of precursors rather than from direct inhibition of macromolecule synthesis, and thereby represent an alteration in plasma membrane function induced by cortisol.

\section{ACKNOWLEDGMENTS}

This work was supported by grants from the U. S. Public Health Service (AM-09865, CA-12790, and TI AM-1004), the Monroe County Cancer and Leukemia Society, and the Atomic Energy Project at the University of Rochester, and has been assigned publication number UR-49-1506.

\section{REFERENCES}

1. Webber, W. A., and J. A. Cairns. 1968. A comparison of the amino acid concentrating ability of the kidney cortex of newborn and mature rats. Can. J. Physiol. Pharmacol. 46 : 165.

2. Webber, W. A. 1968. A comparison of the efflux rates of AIB from kidney cortex slices of mature and newborn rats. Can. J. Physiol. Pharmacol. 46: 765.

3. States, B., and S. Segal. 1968. Developmental aspects of cystine transport in rat intestinal segments. Biochim. Biophys. Acta. 163 : 154.

4. Ning, M., S. Reiser, and P. A. Christiansen. 1968. Variation in intestinal transport of L-valine in relation to age. Proc. Soc. Exp. Biol. Med. 129: 799.

5. Tews, J. K., and A. E. Harper. 1969. Amino acid transport in rat-liver slices during development. Biochim. Biophys. Acta. 183: 635.

6. Foster, D. O., and A. B. Pardee. 1969. Transport of amino acids by confluent and nonconfluent $3 \mathrm{~T} 3$ and polyoma virus-transformed $3 \mathrm{~T} 3$ cells growing on glass cover slips. J. Biol. Chem. 244: 2675.

7. Lesch, M., R. Gorlin, and E. Sonnenblick. 1970. Myocardial amino acid transport in the rabbit right ventricular papillary muscle. Circ. Res. 27: 445.

8. Mendelsohn, J., Sister A. Skinner, and S. Kornfeld. 1971. The rapid induction by phytohemagglutinin of increased $\alpha$-aminoisobutyric and uptake by lymphocytes. J. Clin. Invest. 50: 818.

9. Elsas, L. J. II, R. C. MacDonell, Jr., and L. E. Rosenberg. 1971. Influence of age on insulin stimulation of amino acid uptake in rat diaphragm. J. Biol. Chem. 246: 6452 .

10. Schrek, R. 1964. Prednisolone sensitivity and cytology of viable lymphocytes as tests for chronic lymphocytic leukemia. J. Natl. Cancer Inst. 33: 837.
11. Bartlett, D., Y. Morita, and A. Munck. 1962. Rapid inhibition by cortisol of incorporation of glucose in vivo into the thymus of the rat. Nature (Lond.). 196: 897.

12. Morita, Y., and A. Munck. 1964. Effect of glucocorticoid in vivo and in vitro on net glucose uptake and amino acid incorporation by rat thymus cells. Biochim. Biophys. Acta. 93: 150.

13. Kattwinkel, J., and A. Munck. 1966. Activities in vitro of glucocorticoids and related steroids on glucose uptake by rat thymus cell suspensions. Endocrinology. 79: 387.

14. Munck, A. 1968. Metabolic site and time course of cortisol action on glucose uptake, lactic acid output and glucose-6-phosphate levels of rat thymus cells in vitro. J. Biol. Chem. 243: 1039.

15. Rosen, J. M., J. J. Fina, R. J. Milholland, and F. Rosen. 1970. Inhibition of glucose uptake in lymphoma P 1798 by cortisol and its relationship to the biosynthesis of deoxyribonucleic acid. J. Biol. Chem. 245: 2074.

16. Rosen, J. M., R. J. Milholland, and F. Rosen. 1970. A comparison of the effect of glucocorticoids on glucose uptake and hexokinase activity in lymphosarcoma $\mathrm{P}$ 1798. Biochim. Biophys. Acta. 219: 447.

17. Makman, M. H., B. Dvorkin, and A. White. 1971. Evidence for induction by cortisol in vitro of a protein inhibitor of transport and phosphorylation processes in rat thymocytes. Proc. Natl. Acad. Sci. U.S. A. 68: 1269.

18. Stuart, J. J., and M. Ingram. 1971. The effect of cortisol on viability and glucose uptake in rat thymocytes in vitro. Proc. Soc. Exp. Biol. Med. 136: 1146.

19. Makman, M. H., S. Nakagawa, and A. White. 1967. Studies of the mode of action of adrenal steroids on lymphocytes. Recent Prog. Horm. Res. 23: 195.

20. Makman, M. H., B. Dvorkin, and A. White. 1968. Influence of cortisol on utilization of precursors of nucleic acids and protein by lymphoid cells in vitro. $J$. Biol. Chem. 243 : 1485.

21. Young, D., and G. Klurfeld. 1968. Regulation of protein synthesis in rat thymus cells: in vitro effects of cortisol and substrates on protein and RNA synthesis, and on $\alpha$-aminoisobutyric acid transport. Fed. Proc. 27: 626.

22. Makman, M. H., S. Nakagawa, B. Dvorkin, and A. White. 1970. Inhibitory effects of cortisol and antibiotics on substrate entry and ribonucleic acid synthesis in rat thymocytes in vitro. J. Biol. Chem. 245: 2556.

23. Bray, G. A. 1960. A simple efficient liquid scintillator for counting aqueous solutions in a liquid scintillation counter. Anal. Biochem. 1: 279.

24. Lowry, O. H., N. J. Rosebrough, A. L. Farr, and R. J. Randall. 1951. Protein measurement with the Folin phenol reagent. J. Biol. Chem. 193: 265.

25. Akedo, H., and H. N. Christensen. 1962. Nature of insulin action on amino acid uptake by the isolated diaphragm. J. Biol. Chem. 237: 118 .

26. Dowd, J. E., and D. S. Riggs. 1965. A comparison of estimates of Michaelis-Menten kinetic constants from various linear transformations. J. Biol. Chem. 240: 863.

27. Kay, J. E., and A. Korner. 1966. The effect of cycloheximide on protein and RNA synthesis in cultured human lymphocytes. Biochem. J. 100: 815.

28. Kostyo, J. L., and A. F. Redmond. 1966. Role of protein synthesis in the inhibitory action of adrenal steroid hormones on amino acid transport by muscle. Endocrinology. 79: 531 . 
29. Adamson, L. F., S. G. Langeluttig, and C. S. Anast. 1966. Inhibition by puromycin of amino acid transport by embryonic chick bone. Biochim. Biophys. Acta. 115: 355.

30. Elsas, L. J., and L. E. Rosenberg. 1967. Inhibition of amino acid transport in rat kidney cortex by puromycin. Proc. Natl. Acad. Sci. U. S. A. 57: 371.

31. Elsas, L. J., I. Albrecht, and L. E. Rosenberg. 1968. Insulin stimulation of amino acid uptake in rat diaphragm: relationship to protein synthesis. J. Biol. Chem. $243: 1846$.

32. Young, D. A. 1969. Glucocorticoid action on rat thymus cells. Interrelationships between carbohydrate, protein and adenine nucleotide metabolism and cortisol effects on these functions in vitro. J. Biol. Chem. 244: 2210.

33. Young, D. A. 1970. Glucocorticoid action on rat thymus cells. II. Interrelationships between ribonucleic acid and protein metabolism and between cortisol and substrate effects on these metabolic parameters in vitro. J. Biol. Chem. 245 : 2747.

34. Mosher, K. M., D. A. Young, and A. Munck. 1971. Evidence for irreversible, actinomycin D-sensitive, and temperature-sensitive steps following binding of cortisol to glucocorticoid receptors and preceding effects on glucose-metabolism in rat thymus cells. J. Biol. Chem. 246: 654 .

35. Munck, A. 1971. Glucocorticoid inhibition of glucose uptake by peripheral tissues: old and new evidence, molecular mechanisms, and physiological significance. Perspect. Biol. Med. 14: 265.

36. Baxter, J. D., A. W. Harris, G. M. Tomkins, and M. Cohn. 1970. Glucocorticoid receptors in lymphoma cells in culture: relationship to glucocorticoid killing activity. Science (Wash., D. C.). 171: 189.

37. Kirkpatrick, A. F., R. J. Milholland, and F. Rosen. 1971. Stereospecific glucocorticoid binding to subcellular fractions of the sensitive and resistant lymphosarcoma P 1798. Nature (Lond.). 232 : 216.

38. Cline, M. J. 1967. Prediction of in vivo cytotoxicity of chemotherapeutic agents by their effect on malignant leukocytes in vitro. Blood J. Hematol. 30: 176.

39. Werthamer, S., and L. Amaral. 1971. The response of leukemic lymphocytes to cortisol: a suggested role of transcortin. Blood J. Hematol. 37: 463. 